Journal of Animal and Veterinary Advances 9 (3): 581-583, 2010

ISSN: $1680-5593$

(C) Medwell Journals, 2010

\title{
Effects of Diets with Different Fish Meal Origins on the Performance of Rainbow Trout Oncorhynchus mykiss (Walbaum)
}

\author{
Aysun Kop and Ali Yildirim Korkut \\ Department of Aquaculture, Faculty of Fisheries, Ege University, 35100 Bornova Izmir, Turkey
}

\begin{abstract}
The aim of this trial was to compare the performance of rainbow trout fed diets with different fish meal origin as the main protein sources. The growth trial lasted for 12 weeks and carried out in floating cages $(5 \times 5 \times 5 \mathrm{~m})$, with triplicate groups of 10,500 rainbow trout of an initial average weight of $40 \pm 1.2 \mathrm{~g}$. The experimental diets were formulated to be isonitrogenous and isoenergetic and to include imported (Peru) fish meal (Diet A), locally produced fish meal from Anchovy (Diet B) and locally produced fish meal from several fish species (gilthead sea bream, sea bass and rainbow tout) by-products (Diet C). At the end of the trial, there were no significant differences in the growth rate and protein efficiency ratio among groups ( $p>0.05$ ). Feed conversion ratios were significantly better in groups fed Diets B. It was concluded that, performance of rainbow trout fed practical diets including good quality local processed fish meal are similar to that of fish fed diets including imported fish meal.
\end{abstract}

Key words: Fish meal, local processed fish meal, rainbow trout, growth, experimental diet

\section{INTRODUCTION}

Aquaculture production has expanded at a rate of $15 \%$ per year (Hardy, 2000) and feed costs account for around $50 \%$ of total production costs (Hemre, 2007). Fishmeal is the main protein source used in carnivorous fish diets, namely in marine and fresh water fishes like gilthead sea bream and rainbow trout respectively. Since, the fishmeal has the most adequate amino acid profile, it is a very good source of essential fatty acids and minerals and is highly palatable (Hardy, 2000; Oliva and Gonçalves, 2001; Miles and Chapman, 2006). Global fishmeal production averages between $6.5 \mathrm{mmt}$ year $^{-1}$, of which $23 \%$ is utilized in feeds for farmed fish (Hardy, 2000). Approximately from 4-5 tons of whole fish are required to produce 1 ton of dry fishmeal (Miles and Chapman, 2006). The effiency of the various alternative protein sources as partial or complete dietary replacement for fishmeal has been evaluated in fish diets, e.g., plant protein (Kaushik et al., 2004).

Fish meal is the main protein source in salmonid diets and it is usually the individual feedstuff responsible for the major proportion of diets cost. Traditional pelleted diets for salmonid contains from $40-50 \%$ of protein and most of this protein is gained from fish meal. A large amount of this prtoein is oxidized to produce energy (Kaushik and Médale, 1994). Therefore, reduction in its inclusion level in practical fish diets is a priorty (Hardy, 2000).
Fish meal quality significantly affects rainbow torut performance, consequently, the animal response to modification of the fish meal content of the diets is not independent from fish meal quality (Gomes et al., 1995).

Therefore, the aim of this trial was to compare the performance of rainbow trout fed practical diets including different fish meal origins (locally processed or imported), as the main protein sources.

\section{MATERIALS AND METHODS}

This study was performed by rainbow trout Oncorhynchus mykiss (Walbaum) juveniles. The growth trial was carried out in floating net cages $(5 \times 5 \times 5 \mathrm{~m})$ at the commercial fish farm in Demirkopru Damlake/ManisaTurkey. The fish used were obtained from the same farm.

The experimental diets were formulated to be isonitrogenous and isoenergetic and to include imported (Peru) fish meal (Diet A), locally produced fish meal from Anchovy (Diet B) and locally produced fish meal from several fish species (gilthead sea bream, sea bass and rainbow trout) by-products (Diet C), as the main protein source. Proximate nutritional composition analysis of this fish meals is presented in Table 1 .

Either locally produced fish meal from Anchovy or locally produced fish meal from several fish species by-products were manufactured in a commercial fish meal factory in Turkey. Composition and proximate analysis of the diets are presented in Table 2.

Corresponding Author: A. Kop, Department of Aquaculture, Faculty of Fisheries, Ege University, 35100 Bornova Izmir, Turkey 


\begin{tabular}{|c|c|c|c|}
\hline $\begin{array}{l}\text { Proximate } \\
\text { analy sis } \\
\text { (Dry matter \%) }\end{array}$ & $\begin{array}{l}\text { Imported } \\
\text { fish meal } \\
\text { from peru }\end{array}$ & $\begin{array}{l}\text { Locally produced } \\
\text { fish meal } \\
\text { from Anchovy }\end{array}$ & $\begin{array}{l}\text { Locally produced } \\
\text { fish meal from } \\
\text { fish by-product }\end{array}$ \\
\hline Dry matter & $92 \pm 1.28$ & $92 \pm 1.50$ & $94 \pm 1.21$ \\
\hline Protein & $65.5 \pm 0.9$ & $72 \pm 1.25$ & $51.71 \pm 1.30$ \\
\hline Lipids & $8.8 \pm 0.23$ & $9.1 \pm 0.36$ & $10.15 \pm 0.93$ \\
\hline Crude fibre & $0.3 \pm 0.03$ & $0.51 \pm 0.02$ & $2.57 \pm 0.09$ \\
\hline Ash & $15.9 \pm 0.51$ & $16.7 \pm 0.67$ & $18.54 \pm 0.91$ \\
\hline $\mathrm{Ca}$ & $3.4 \pm 0.32$ & $3.61 \pm 0.25$ & $5.28 \pm 0.17$ \\
\hline$\underline{P}$ & $1.95 \pm 0.26$ & $2.16 \pm 0.15$ & $2.94 \pm 0.21$ \\
\hline
\end{tabular}

Table 2: Composition and proximate analysis of the experimental diets

\begin{tabular}{llll}
\hline Items & Diet A & Diet B & Diet C \\
\hline Ingredients (g kg & \\
Fish Meal, imported & & & \\
Fish Meal, locally produced & 40 & - & - \\
Fish Meal, fish by-product & - & 37 & - \\
Fish oil (Peru) & - & - & 48 \\
Soybean meal (44\% CP) & 9.5 & 9 & 8 \\
Wheat meal & 23.2 & 23 & 21.5 \\
Wheat gluten & 19.34 & 23.04 & 14.54 \\
Nupro & 6 & 6 & 6 \\
Biomoss & 0.5 & 0.5 & 0.5 \\
Vitamine mix. & 0.1 & 0.1 & \\
Minerale mix. & 0.5 & 0.5 & 0.5 \\
Mycosorb & 0.4 & 0.4 & 0.4 \\
Sel-Pex & 0.05 & 0.05 & 0.05 \\
Binder & 0.01 & 0.01 & 0.01 \\
Total & 0.5 & 0.5 & 0.5 \\
Proximate analysis (Dry matter \%) & 100 & 100 & 100 \\
Dry matter & 88.03 & 89.51 & 89.17 \\
Protein & 44.25 & 44.29 & 44.26 \\
Lipids & 14.03 & 14.18 & 14.17 \\
Crude fibre & 1.71 & 1.76 & 1.06 \\
Ash & 8.13 & 7.29 & 9.52 \\
Energy (Kcal) & 3244 & 3272 & 3198 \\
Total feed costs & $0.86 \$$ & $0.93 \$$ & $0.71 \$$ \\
\hline
\end{tabular}

a Provided per kg of diet: $15 \mathrm{mg}$ of vitamin A $\left(500,000 \mathrm{IU} \mathrm{g}^{-1}\right) ; 15 \mathrm{mg}$ of vitamin D3 $\left(100,000 \mathrm{IU} \mathrm{g}^{-1}\right) ; 60 \mathrm{mg}$ of vitamin $\mathrm{E}\left(500 \mathrm{IU} \mathrm{g}^{-1}\right) ; 2.5 \mathrm{mg}$ of vitamin $\mathrm{K} ; 7.5 \mathrm{mg}$ of thiamin; $15 \mathrm{mg}$ of riboflavin; $7.5 \mathrm{mg}$ of pyridoxine; $87.5 \mathrm{mg}$ of nicotinic acid; $2.5 \mathrm{mg}$ of folic acid; $25 \mathrm{mg}$ of vitamin B12 $\left(1,000 \mathrm{mg} \mathrm{kg}^{-1}\right) ; 5 \mathrm{~g}$ of inositol; $62.5 \mathrm{mg}$ of biotin (2\%); $25 \mathrm{mg}$ of calcium pantothenate; $2 \mathrm{~g}$ of choline (50\%)

At the start of the trial, 9 groups of 10,500 fish with an average individual weigth of $40 \pm 1.2 \mathrm{~g}$ were assembled in square floating cages. Stocks density was $20 \mathrm{~kg} \mathrm{~m}^{-3}$ in each cage and total amount of 63 fish were used in this trial.

Each experimental diet (A-C) was fed to triplicate groups of fish. The trial lasted for 12 weeks and during the experiment, water temperature averaged $14^{\circ} \mathrm{C}$. During the study, the fish were hand fed twice a day to feeding schedule for rainbow trout. The fish were measured and weighed every 2 weeks and the food consumed in this period was recorded.

Feed Conversion Ratio (FCR), Spesific Growth Rate (SGR) and Protein Efficiency Ratio (PER) of the fish were calculated as follows (Barrias and Teles, 2000):

$$
\mathrm{FCR}=\frac{\text { Feed intake }}{\text { Weight gain }}
$$

$$
\begin{gathered}
\mathrm{SGR}=\frac{\ln \text { final weight (days) }}{\ln \text { initial weight (days) }} \\
\mathrm{PER}=\frac{\text { Weight gain }}{\text { Protein intake }}
\end{gathered}
$$

In addition, the costs of the diets used in the study and the total diet expenditures at the end of the experiment are calculated as follows:

$$
\begin{aligned}
\text { Feed cost }= & \text { Total consumption feed amount }(\mathrm{kg}) \times \\
& \text { Feed cost }
\end{aligned}
$$

Chemical analysis of the diets and each fish meals (crude protein, moisture, fat, fiber and ash) were made by using the Association of Official Analytical Chemists (AOAC, 1985) methods.

Statistical analysis consisted of one-way ANOVA, using the probability level of 0.05 for rejection of the null hypothesis. After ANOVA, significant differences among means were determined by Tukey's multiple range test. All statistical analysis was performed using SPSS 11.0 for a Windows.

\section{RESULTS AND DISCUSSION}

Data on growth performance of the fish during the trial are presented in Table 3 . Growth was not significantly different among groups ( $>0.05$ ). The feed conversion ratio and SGR of trout fed diets $\mathrm{C}$ was significantly higher $(\mathrm{p}<0.05)$ than $\mathrm{A}$ and $\mathrm{B}$. There were no significant differences among groups in terms of protein efficiency ratio.

In this trial, there were no significant differences in growth among groups. In rainbow trout, Watanabe et al. (1983) and Barrias and Teles (2000) also compared the performance of fish fed diets including different fish meals as the only protein source. No significant differences were found in growth and diet utilization.

In this study, though no difference was found between the groups in terms of especially SGR and FCR values, these values are at the acceptable level in nutrition of carnivorous species such as carnivore $(\mathrm{p}<0.05)$. Emre (2004), suggests that 1.2-1.4 feed conversion rate in tanks is sufficient for carnivore fish production. However, the point here is about the differences between the costs of such types of diets, their amounts of use and the diet expenditures contingent on them.

Table 1 shows the raw protein values of fish meal used in the experiment. According to this, the highest protein values belong to anchovy, Peru and fish by product, respectively. Table 3 shows the total amounts of 
Table 3: Growth and feed utilization of rainbow trout fed the experimental

\begin{tabular}{llll}
\multicolumn{1}{c}{ diets } & Diet A & Diet B & Diet C \\
\hline Parameters & $40.21 \pm 2.10$ & $40.17 \pm 1.50$ & $40,18 \pm 1.20$ \\
Initial weigth (g) & $249.45 \pm 2.73$ & $251.28 \pm 2.15$ & $227.15 \pm 3.86$ \\
Final weigth (g) & $2.02 \pm 0.02^{\mathrm{a}}$ & $1.84 \pm 0.01^{\mathrm{a}}$ & $2.83 \pm 0.03^{\mathrm{b}}$ \\
SGR (\%) & $0.996 \pm 0.120^{\mathrm{a}}$ & $0.967 \pm 0.110^{\mathrm{a}}$ & $1.229 \pm 0.15^{\mathrm{b}}$ \\
FCR & $1.955 \pm 0.010$ & $2.178 \pm 0.020$ & $1.869 \pm 0.04$ \\
PER & & & \\
Total consumption feed & 818.43 & & \\
amount (kg) & & & \\
\hline
\end{tabular}

consumption of the diets prepared with these fish meals. The lowest consumed diets are Diet B, Diet A and Diet C, respectively. Since the fish meal produced by anchovy contains higher HP, it is foreseeable that the lowest diet consumption occurs in this group. Similarly, the highest diet consumption occurs in the Diet $\mathrm{C}$ group due to its low HP content.

However, when these groups are compared in terms of diet cost, it becomes evident that the Diet B loses its advantage. The highest diet costs belong to Diet B, A and $\mathrm{C}$, respectively (Table 2). Though the Diet $\mathrm{C}$ is the cheapest diet, it has the highest diet consumption rate due to its low HP content. The total diet expenditures of the groups are; $703,85 \$$ for the Diet A, $752,97 \$$ for the Diet $\mathrm{B}$ and $641,04 \$$ for the Diet C. Even though the Diet C is a cheap diet, its FCR value is 1,229 and it is higher than the other groups.

\section{CONCLUSION}

All types of fish meals used in this study are usable resources in carnivore production without having negative effects on growth.

\section{REFERENCES}

AOAC, 1985. Official Methods of Analysis Association of Official Analysis Chemists. AOAC, Washington, DC., USA.

Barrias, C. and A.O. Teles, 2000. The use of locally produced fish meal and other dietary manipulations in practical diets for rainbow trout Oncorhynchus mykiss (Walbaum). Aquac. Res., 31: 213-218.
Emre, Y., 2004. Alabalik yetisticiligi. T.C Basbakanlık Güneydoguanadolu Projesi Bölge Kalkınma Idaresi Baskanligi, pp: 1-17. http://www.gap.gov.tr/Turkish/ Tarim/Suurunyt/alabalik.pdf.

Gomes, E.F., P. Rema, A. Gouveia and A.O. Teles, 1995. Replacement of fish meal by plant proteins in diets for rainbow trout Oncorhynchus mykiss: Effect of the quality of the fish meal based control diets on digestibility and nutrient balances. Water Sci. Technol., 31: 205-211.

Hardy, W.R., 2000. New Developments in Aquatic Feed Ingredients and Potential of Enzyme Supplements. In: Advances en Nutrición Acuícola V. Memorias del V Simposium Internacional de Nutrición Acuícola, Cruz-Suarez, L.E., D. Ricque-Marie, M. Tapia-Salazar, M.A.Y. Olvera-Novoa and R. Civera-Cerecedo (Eds.). Mérida, Yucatán, Mexico, pp: 216-226.

Hemre, G.I., 2007. Effect of Replacing Fish Oil and Fish Meal in Aquaculture Diets on Growth, Feed Utilisation and Product Quality. Institute of Nutrition, Directorate of Fisheries, Bergen, Norway.

Kaushik, S.J. and F. Médale, 1994. Energy requirement, utilization and dietary supply to salmonids. Aquaculture, 124: 81-97.

Kaushik, S.J., D. Coves, G. Dutto and D. Blanc, 2004. Almost total replacement of fish meal by plant protein sources in the diet of marine teleost, the European seabass, Dicentrarchus labrax. Aquaculture, 230: 391-404.

Miles, R.D. and F.A. Chapman, 2006. The Benefits of Fish Meal in Aquaculture Diets. IFAS, Florida.

Oliva, T.A. and P. Gonçalves, 2001. Partial replacement of fishmeal by berewers yeast (Saccaromyces cerevisiae) in diets for sea bass (Dicentrarchus labrax) juveniles. Aquaculture, 202: 269-278.

Watanabe, T., H. Nanri, S. Satoh, M. Takeuchi and T. Nose, 1983. Nutritional evaluation of brown meals as a protein source in diets for rainbow trout. Bull. Jap. Soc. Sci. Fish., 49: 1083-1087. 